\title{
Ochrona dzieci - praktyczne doświadczenia ze wsparciem dla rodzin dysfunkcyjnych w Czechach
}

\begin{abstract}
This article is about supporting dysfunctional families, in which children are neglected and parents do not fulfill their parental responsibilities. The whole article is based on the practice of children's centers, which is based on the principles and processes of deinstitutionalisation in the implementation of social and legal protection of children.
\end{abstract}

Keywords: family rehabilitation, child neglect, child's needs, deinstitutionalisation, social and legal protection of children

\section{Wprowadzenie}

/ $\begin{aligned} & \text { raz z przystąpieniem do Unii Europejskiej Republika Czeska bardziej zaanga- } \\ & \text { żowała się w procesy deinstytucjonalizacji, pomagając osobom zagrożonym }\end{aligned}$ wykluczeniem społecznym. Istnieje kilka takich grup - osoby niepełnosprawne, osoby starsze, dzieci krzywdzone i zaniedbywane, żyjący w obszarach wykluczonych społecznie. Prezentowany artykuł dotyczy charakterystyki rodzin zaniedbujących wykonywanie obowiązków rodzicielskich oraz praktycznych doświadczeń w pracy z tymi rodzinami. Opis zmian ukazany w różnych podejściach jest motywowany wprowadzeniem zasady deinstytucjonalizacji do systemu ochrony socjalnej i prawnej dzieci (SPOD) oraz związanych z tym norm prawnych i procesu ich zmian. Skupiam się tu na rodzinach, w których dochodzi do zaniedbywania 
dziecka przez rodziców. Jest to szerokie spektrum problemów rodzin, z którymi można pracować nad wsparciem w uzdrowieniu rodziny.

Pierwsza część artykułu przedstawia historyczny kontekst zmian, oceny kompetencji rodzicielskich w kontekście zaspokajania potrzeb dzieci oraz podstawowe dane statystyczne związane z wynikami SPOD.

Główna część poświęcona jest pracy zawodowej z rodzinami, których członkowie nie wypełniają odpowiednio roli rodzicielskiej. Artykuł porusza jedynie wybrany obszar problemów tych rodzin i zasady pracy z rodzinami. Wszystkie charakteryzowane doświadczenia opierają się na wynikach bezpośredniej pracy z rodzinami. Wyniki te pochodzą z doświadczeń takich instytucji, jak: Centrum Dziecka Čtyřlístek - Opava i Havîrov, Centrum Dziecka Veská - Pardubice i Holice, Centrum Dziecka Strakonice. W szczególności są to procedury wsparcia rodziny, w której żyją dzieci zaniedbywane i pozostawione same sobie.

\section{Kontekst historyczny. Zasady oceny kompetencji rodzicielskich rodziców}

W Czechach i na Słowacji kwestia ochrony dzieci była ważnym aspektem nadzoru państwa nad rodziną. Od rewolucji komunistycznej (komunistycznego zamachu stanu w 1948 r.) zasady SPOD opierały się wyłącznie na ochronie dziecka ${ }^{1}$, a wszelka pomoc dla dziecka miała miejsce jedynie w placówkach instytucjonalnych. Opiekę zastępczą uchylono ustawą o ochronie socjalnej i prawnej młodzieży (Dz. U. z 1952 r. Nr 69). Ustawa ta w § 9 wskazuje:

Jeżeli dziecko musi zostać powierzone opiece zastępującej opiekę rodziców, co do zasady będzie ono objęte opieką zbiorową; w przeciwnym razie dziecko może zostać umieszczone tylko w rodzinie, która gwarantuje wychowanie dziecka w poszanowaniu zasad demokratycznego państwa i jest w stanie zapewnić mu warunki sprzyjające jego rozwojowi, zwykle w wyniku adopcji dziecka.

Zgodnie z tym prawem opieka zastępcza w Republice Czeskiej zdecydowanie przestaje istnieć i jest możliwa tylko przez adopcję. Inne formy opieki mają charakter instytucjonalny. Pierwsze zmiany w całym systemie zaczęły mieć miejsce w latach 60. ubiegłego wieku, kiedy trzech autorów: Zdeněk Matějček, Josef Langmeier, Jiří Dunovský publikowało swoje badania na temat wczesnej deprywacji dzieci z przewlekłymi chorobami, hospitalizowanymi przez długi czas w szpitalach, a także opisujące wpływ na psychikę dzieci objętych opieką instytucjonalną w żłobkach od ukończenia 6. miesiąca życia. Sytuacja ta była spowodowana krótkim okresem urlopu macierzyńskiego, kiedy to kobiety miały pomóc w budowaniu socjalizmu.

${ }^{1}$ N. Gilbert, N. Parton, M. Skivenes, Child protection systems: international trends and orientations, Oxford University Press, New York 2011, s. 273. 
Jeden z tych autorów - Dunovský (czeski pediatra społeczny) zawodowo poświęcił się wychowaniu dzieci, które wykazywały tzw. syndrom CAN². Natomiast Langmeier i Matějček bardziej skupili się na psychice i potrzebach dzieci. Ich filmowy dokument „Dzieci bez miłości” przyniósł zasadniczą zmianę w postrzeganiu tego problemu. Wyniki swoich obserwacji opisują oni w książce Deprywacja psychiczna w dzieciństwie ${ }^{3}$. W tym samym czasie publikacje Johna Bowlby’ego o teorii przywiązania - są już rozpowszechnione na całym świecie 4 .

\section{Potrzeby dziecka - wypełnianie roli rodzicielskiej}

Wspomniani autorzy określają podstawowe potrzeby dzieci. Ich wypełnianie stanowi wyraz prawidłowego rodzicielstwa - świadomości jego wad, ale także wysiłków na rzecz bliskich więzi z dzieckiem i rozumienia jego potrzeb. W przeciwieństwie do tego, niespełnienie tych wymogów i bierne podejście rodzica do potrzeb dziecka określa się jako brak kompetencji rodzicielskich i brak odpowiedzialności rodzicielskiej oraz zaniedbanie dziecka - ujawniane jako syndrom CAN. Wymienione kwestie (w tym zaspokajanie potrzeb wskazanych poniżej) są od dawna narzędziem oceny kompetencji rodzicielskich ze strony pracowników socjalnych SPOD w Czechosłowacji i odgrywają ważną rolę do dziś.

Potrzeby rozwojowe dzieci:

- potrzeba stymulacji - dziecko ciągle potrzebuje odpowiednich bodźców w wystarczającym stopniu dostarczanych przez wystarczająco długi czas, ale przede wszystkim bodźców odpowiadających jego etapowi rozwoju. Na przykład dziecko poniżej 3. roku życia nie potrzebuje bajki w telewizji, ale bajki opowiadanej przez rodzica. Takie bodźce wspierają aktywność psychiczną dziecka, a jednocześnie służą jako podstawowy grunt do uczenia się i rozwijania kreatywności;

- potrzeba usensowionego świata - oznacza, że wiele bodźców, które otrzymuje dziecko, buduje wiedzę i doświadczenie. Dziecko musi znać zasady i porządek, zgodnie z którymi działa świat, w którym żyje i które są ważne dla innych. W ten sposób kształtuje się świadomość, zachowanie i osobowość jednostki;

- potrzeba bezpieczeństwa - potrzeby tego obszaru są zaspokajane, jeśli dziecko może żyć w pewnych i bezpiecznych relacjach interpersonalnych, pośród bliskich w swojej kochającej rodzinie. Ten związek z bliskimi musi być wzajemny, głęboki i trwały. Dziecko uczy się nie tylko otrzymywać miłość, ale także ją odwzajemniać. Ryzykiem są ciągle zmieniające się zasady, które wprowadzają dziecko w błąd. Natomiast poczucie pewności pozwala dziecku na swobodne odkrywanie świata;

${ }^{2}$ Syndrom CAN oznacza zaniedbywanie dzieci i nadużycia wobec nich, m.in. przemoc i maltretowanie.

3 J. Langmeier, Z. Matějček, Psychická deprivace v dětství, Karolinum, Praha 2011.

${ }^{4}$ Zob. np. J. Bowlby, Vazba: teorie kvality raných vztahů mezi matkou a dítětem, Portál, Praha 2010. 
- potrzeba uznania społecznego - wiąże się z kształtowaniem pewności siebie u dziecka, jego samooceny i uznania własnej wartości. W dzieciństwie tę potrzebę zaspokaja się dzięki stymulacjom ze strony rodziców. Daje to szansę odpowiedzi na pytania, kim jestem, jakie mam znaczenie dla innych;

- potrzeba „otwartości na przyszłość” - realizowana w akceptowalny przez jednostkę sposób, pozwala jej potwierdzić własną wartość lub inną możliwość rozwoju w przyszłości. Utrata perspektywy życiowej („zamknięcie na przyszłość”) prowadzi do rozpaczy, beznadziejności ${ }^{5}$.

\section{Deprywacja w rodzinie}

Wszystkie dzieci wchodzące do systemu SPOD wykazują długotrwały deficyt wszystkich wyżej wymienionych potrzeb, które są niezbędne do ich pomyślnego rozwoju. Zanim pracownik socjalny wejdzie do rodziny, dziecko jest już w pewnym stopniu pozbawione zaspokojenia tychże potrzeb. Dziecko nie wchodzi zatem do systemu SPOD jako osoba bez problemów (np. depresji), ale jako osoba, która ma już za sobą pewien stopień deprywacji. Stopień deprywacji jest wprost proporcjonalny do długości życia i pobytu w pierwotnej rodzinie oraz siły środowiska deficytowego. Paradoks SPOD z punktu widzenia pracownika socjalnego polega na tym, że to nie instytucja, a rodzina biologiczna, pozostawiła własne dziecko bez rodziny.

Obecnie SPOD, odnosząc się do CAN, rozróżnia:

- znęcanie się (forma aktywna) - fizyczne i seksualne,

- zaniedbanie (forma pasywna) - niespełnienie podstawowych potrzeb dziecka.

Odnosi się to do wskazania, że każde fizyczne wykorzystywanie dziecka wiąże się również z zaniedbaniem, ale nie każde zaniedbanie wiąże się z aktywną formą wykorzystywania.

\section{Pochodzenie społeczne z perspektywy dzieci}

Ogólnie w Czechach obowiązuje obecnie długi urlop rodzicielski - do 4 lat. Opieka przez placówki medyczne zwalnia z tego urlopu. Ważną kwestią są także zarejestrowane związki partnerskie, legalizowane ustawą o partnerstwie (Dz. U. z 2006 r. Nr 115). Z punktu widzenia dzieci zmieniają się formy relacji, w których się rodzą lub w których się znajdują.

We wcześniejszym podejściu do rodziny z dzieckiem, dzieci wychowywane były:

- w małżeństwie,

${ }^{5}$ Z. Matějček, Co děti nejvíc potřebují: Eseje z dětské psychologie, Portál, Praha 1994, s. 108. 
- przez samotnych rodziców,

- w rodzinach z nowymi partnerami.

Nowe podejście zakłada, że dzieci mogą być wychowywane przez:

- partnerów małżeńskich,

- niezamężnych partnerów,

- partnerów tej samej płci,

- partnerów „w połowie drogi” (są to relacje, w których każdy z rodziców ma własne gospodarstwo domowe, a dziecko funkcjonuje naprzemiennie między nimi),

- samotnych lub rozwiedzionych rodziców,

- w rodzinach z nowymi partnerami - tzw. rodzina patchworkowa.

Dzieci zagrożone wykluczeniem społecznym nie istnieją w systemie czeskiej pomocy społecznej, dopóki nie rozpoczną edukacji szkolnej. W Republice Czeskiej obowiązkiem szkolnym objęte są dzieci, które ukończyły 6. rok życia i rozpoczynają edukację przedszkolną. Do tego momentu, z powodu małej liczby lekarzy pediatrów oraz ograniczonego nadzoru nad małymi dziećmi, system może nie wiedzieć o dziecku zagrożonym wykluczeniem społecznym. Są także dzieci, o których urodzeniu państwo nie wie, nie posiada o nich żadnych formalnych informacji 6 .

\section{Zmiana paradygmatu i przepisów prawnych}

Zasadnicze zmiany w czeskim prawie weszły w życie w 2013 i 2014 r. Republika Czeska wprowadziła znaczącą reformę systemu pomocy społecznej w 2013 r. Zmiany te zmieniają ochronę socjalną i prawną pod względem celów, narzędzi i procesów w zakresie funkcjonowania SPOD. Wraz z nadejściem zmian w 2013 r. zmienia się paradygmat zapewniania ochrony socjalnej i prawnej dzieciom, preferowane jest dobro dziecka. Nowelizacja ustawy o społecznej i prawnej ochronie dzieci (Dz. U. z 1999 r. Nr 359) z dniem 1 stycznia 2013 r. wprowadza system deinstytucjonalizacji i przeniesienia podopiecznych do rodzinnych form pomocy. Istniejącą opiekę zastępczą rozumie się tylko jako tymczasową formę pomocy, a jej celem jest powrót dziecka do biologicznej rodziny - zgodnie z paradygmatem Family Service ${ }^{7}$.

W nowelizacji ustawy o społecznej i prawnej ochronie dzieci do 1 stycznia 2013 r. głównym elementem socjalnej ochrony prawnej było zabezpieczenie „podstawowych interesów dziecka”. W obecnym prawodawstwie wprowadzono kilka zmian:

Zgodnie z § 5 ustawy o społecznej i prawnej ochronie dzieci:

${ }^{6}$ W Czechach istnieją „okna życia”. Nie wiemy, kim są rodzice porzucanych dzieci. Jeśli był to poród domowy, dziecko nie musi być wymienione w systemie rejestru.

${ }^{7}$ N. Gilbert, N. Parton, M. Skivenes, Child protection systems..., s. 273. 
Podstawowym aspektem ochrony socjalnej i prawnej jest dobro dziecka, ochrona rodzicielstwa i rodziny oraz wzajemne prawo rodziców i dzieci do edukacji i opieki rodzicielskiej. Jednocześnie brane jest pod uwagę szersze środowisko społeczne dziecka.

W związku z nowym kodeksem cywilnym (Dz. U. z 2012 r. Nr 89, w § 971, ust. 3): „Niewystarczające warunki mieszkaniowe lub majątkowe rodziców dziecka lub osób, którym powierzono opiekę nad dzieckiem, same w sobie nie mogą być powodem decyzji sądu o opiece instytucjonalnej, jeżeli rodzice mają inne możliwości do zapewnienia odpowiedniego wychowania dziecka i wypełnienia innych obowiązków wynikających z ich odpowiedzialności rodzicielskiej”, zaniedbanie dziecka w ubogim gospodarstwie domowym uważa się za spowodowane względami społecznymi. Innymi słowy, zakłada się, że rodzic chce być dobrym rodzicem, ale na przykład ubóstwo mu to uniemożliwia. To rozwiązanie stara się utrzymać dziecko w jego naturalnym środowisku tak długo, jak to możliwe, niemal za wszelką cenę (rozporządzenie nr 473, Dz. U. z 2012 r., § 1). Istnieje zasadnicza różnica przed nowelizacją prawa założono, że dziecko może zaspokoić wszystkie swoje potrzeby nawet w złych warunkach, że dobre rodzicielstwo jest cechą osobowości. W obecnym prawodawstwie zakładamy, że dobre rodzicielstwo jest pod pewnymi względami zależne od siły ekonomicznej rodziny lub jednostki. Badanie Schramma ${ }^{8}$ zauważa, że dobre interakcje między rodzicami mogą zrównoważyć złą sytuację ekonomiczną rodziny i jej negatywny wpływ na dziecko, natomiast dysfunkcyjny związek w sytuacji braku funduszy zagraża dziecku. Badanie to identyfikuje rodziny niepełne lub rodziny kohabitacyjne jako niestabilne. W swojej publikacji odnoszącej do ochrony dziecka ${ }^{9}$, Neil Gilbert rozróżnia również formy aktywne i pasywne. Zwraca jednak uwagę na zmianę, w której dobre rodzicielstwo jest silnie zbudowane na poziomie sytuacji ekonomicznej i społecznej rodziny, a nie na osobistych cechach osoby dorosłej. Nowym zadaniem pracownika socjalnego jest ochrona dziecka (zob. § 5 ustawy o społecznej i prawnej ochronie dzieci ${ }^{10}$ ).

Tabela 1. pokazuje, że większość dzieci w systemie SPOD jest zaniedbana. W przypadku niepowodzenia wsparcia rodziny dzieci te zwykle przechodzą pod opiekę zastępczą sprawowaną przez dziadków, co stanowi około 65\% opieki zastępczej w Czechach.

${ }^{8}$ D. Schramm, T. Utris, R. Bradley, Child Welfare and Healthy Marriage and Relationship Education: A Research to Practice Brief, 2013, https://library.healthymarriageandfamilies.org/cwig/ws/library/docs/MARRIAGE/Blob/85819.pdf?w=NATIVE(\%27TITLE+ph+ is+\%27\%27Child+Welfare+and+Healthy+Marriage+and+Relationship+Education:+A+Re search+to+Practice+Brief\%27\%27\%27)\&upp=0\&rpp=25\&order=native(\%27year/Descen$\mathrm{d} \% 27) \& \mathrm{r}=1 \& \mathrm{~m}=1$ [20.12.2019].

${ }_{9}$ N. Gilbert, N. Parton, M. Skivenes, Child protection systems..., s. 273.

10 „Podstawowym aspektem ochrony socjalnej i prawnej jest interes dziecka oraz jego dobro, ochrona rodzicielstwa i rodziny, a także wzajemne prawo rodziców i dzieci do edukacji i opieki rodzicielskiej. Jednocześnie brane jest pod uwagę szersze środowisko społeczne dziecka”. 


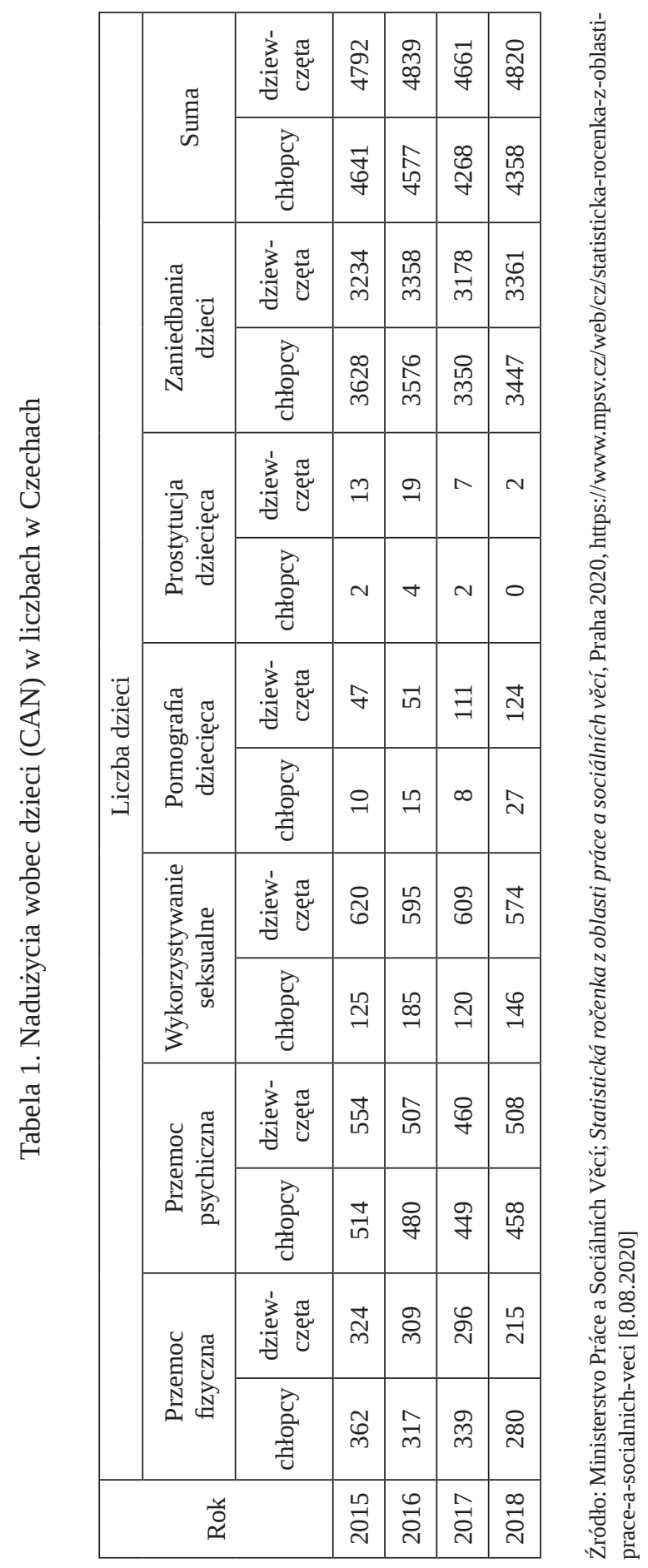




\section{Ośrodki dla dzieci - narzędzie do rehabilitacji i uzdrawiania rodzin}

Ośrodki dla dzieci powstają w wyniku przekształcenia placówek dla niemowląt w procesie deinstytucjonalizacji, co znalazło następnie odzwierciedlenie w ustawie o usługach zdrowotnych (Dz. U. 2011 r. Nr 372). Utworzone ośrodki dla dzieci szukały nowego podejścia do potrzeb rodzin. Chciano wówczas wykorzystać wieloletnie doświadczenie w pracy z zagrożonymi dziećmi i rodzinami, które potrzebują specjalnej pomocy.

Historycznie ośrodki dla dzieci stanowiły trzon procesów ochrony dzieci zagrożonych przed nadużyciami (CAN), były one ośrodkami przyjmowania i przygotowywania osób ubiegających się o opiekę zastępczą. Ich zespoły obejmują pediatrów, psychologów, terapeutów, pielęgniarki i pracowników socjalnych. Historycznie pracowali oni wspólnie także z rodzinami, w których urodziło się niepełnosprawne dziecko. W 2007 r. dyrektorzy placówek wsparcia założyli Związek Dziecięcych Placówek Medycznych (Fabián - Centrum Dziecka Čtyřlístek w Opawie i Havířovie, Novotný - Centrum Dziecka w Ostrawie, Rýznar - Centrum Dziecka pavučinka w Šumperku) i tym samym chcieli wprowadzać procesy deinstytucjonalizacji, aby zbudować nowe formy pomocy dziecku. Ich zespoły połączyły wieloletnie doświadczenie i wiedzę niezbędne do zmiany tych procesów i umożliwiły wejście do specjalistycznych ośrodków inspirowanych ośrodkami dziecięcymi z Niemiec ${ }^{11}$. Szybko znaleziono współpracowników w innych ośrodkach dla dzieci w Czechach.

Równolegle weszła w życie nowa ustawa o usługach społecznych (Dz. U. z 2006 r. Nr 109), która umożliwiła rozpoczęcie tych zmian, szczególnie określonych w punkcie 65 jako: „Usługi aktywizacji społecznej dla rodzin z dziećmi”.

1. Usługi aktywizacji społecznej dla rodzin z dziećmi są świadczeniami doraźnymi (bądź opcjonalnymi) lub ambulatoryjnymi świadczonymi na rzecz rodziny z dzieckiem, której rozwój jest zagrożony z powodu skutków długotrwałej kryzysowej sytuacji społecznej, której rodzice nie są w stanie samodzielnie pokonać bez pomocy, i gdzie istnieje inne ryzyko narażenia go na niebezpieczeństwo w rozwoju.

2. Usługa, o której mowa w ust. 1, obejmuje następujące podstawowe czynności:

a) działania edukacyjne, szkoleniowe i aktywacyjne,

b) pośrednictwo w kontaktach ze środowiskiem społecznym,

c) działania socjoterapeutyczne,

d) pomoc w realizowaniu praw, uzasadnionych interesów i zaspokojeniu potrzeb osobistych".

W praktyce jest to usługa, która może być świadczona na dwa sposoby:

${ }^{11}$ F. Schneiberg, Dětská centra - moderní forma komplexní péče o ohrožené děti, Pediatrie pro praxi, s.136,137 ISSN 1213-0494, https://www.pediatriepropraxi.cz/pdfs/ped/2011/02/20. pdf [28.12.2019]. 
1. Jako usługa terenowa. Jest świadczona w rodzinnym domu. Pracownik socjalny przychodzi do rodziny zgodnie z ustalonym planem i wykonuje czynności zgodnie z wymogami pracy socjalnej.

2. Jako usługa mieszkaniowa. Rodzina zostaje przyjęta do ośrodka dziecięcego, w którym może otrzymać specjalistyczne wsparcie. Pracuje się tu specjalistycznie z rodziną, a następnie, po nabyciu pewnych kompetencji, wraca ona do normalnego środowiska społecznego.

\section{Proces pracy z rodziną i dzieckiem}

Jednym z pierwszych, który rozpoczął pracę z rodziną dziecka zagrożonego syndromem CAN był zakład położony w regionie pardubickim - Centrum Dziecka Veská (Pardubicei Holice), a także w regionie morawsko-śląskim - Centrum Dziecka Čtyřlístek (Opawa i Haviŕov).

Podstawową procedurą współpracy z pracownikami socjalnymi OSPOD była oferta usług, która dotyczyła pomocy kryzysowej dla dziecka, a jednocześnie pomocy dla rodziny. Usługi te skoncentrowane były w ofercie takich działań, jak:

- pomoc kryzysowa dla dziecka,

- możliwość pomocy ambulatoryjnej dla rodziny,

- możliwość świadczenia usług mieszkaniowych dla rodziny - zakwaterowanie rodziców z dzieckiem w obiekcie i praca z całym systemem rodzinnym.

Współpraca z rodziną zwykle zaczynała się w momencie przekazania dziecka do ośrodka (centrum kryzysowego) na okres trzech miesięcy. Rodzina uzyskiwała wtedy pomoc terapeutyczną. Dziecko zostaje wówczas umieszczone w centrum kryzysowym na prośbę rodziców, przy rekomendacji pracownika socjalnego odpowiedniego departamentu SPOD w danym mieście. Standardowy proces pracy z dzieckiem oznacza umieszczenie dziecka w mieszkaniu, jakim dysponuje placówka pomocy (mieszkania komunalne), wraz z rodzeństwem lub innymi dziećmi (z maksymalnie czwórką dzieci). Dzieci są umieszczone w domu, chodzą do szkoły, a po południu mają własny program terapeutyczny i rekreacyjny. Każde dziecko ma prowadzącego pracownika, który zarządza procesem pracy, a także ocenia proces zmiany.

Po pięciu latach doświadczeń (w latach 2008-2013) scharakteryzowane zostały podstawowe typy rodzin, które wymagały wsparcia. Opis ten jest zdefiniowany zgodnie z rodzicielskim podejściem do dziecka i z uwzględnieniem zmian zachodzących w obrębie instytucji rodziny. 


\section{Rodziny z wykształconymi przekonaniami}

W takich rodzinach podstawowym elementem w kontaktach z rodzicami lub osobami odpowiedzialnymi za edukację jest absolutne przekonanie, że ich podejście edukacyjne jest właściwe. Jeśli pracownikom socjalnym, nauczycielom lub pracownikom służby zdrowia się to nie podoba - to ich wina.

Podejścia do współpracy:

1. Współpracę określa się w kategoriach obowiązku pracowników socjalnych i groźby postępowania karnego.

2. Odnotowuje się wszechstronną niechęć rodziców do zmiany postaw wobec dziecka lub zmian poglądów dotyczących potrzeb dziecka w zakresie obowiązków rodzicielskich.

Współpraca z tymi rodzinami kończy się szybko, dziecko zwykle umieszczone jest w rodzinie zastępczej. Wówczas odejście dziecka od rodziny traktowane jest jako uwolnienie rodziny od mechanizmów kontroli przez instytucję. Ponadto rodzice nie wykazywali zainteresowania dzieckiem, nawet w sytuacji motywowania ich przez instytucje towarzyszące, które są odpowiedzialne za współpracę z biologiczną rodziną dziecka.

\section{Rodziny, które posiadają alibi - „naprawa” dziecka}

Tego rodzaju rodziny są ciekawe głównie dlatego, że po ich ostrzeżeniu przez placówkę edukacyjną o nieprawidłowym zachowaniu dziecka, wobec którego placówka pozostaje bezradna, zwykle prosiły one o pomoc w wychowaniu (naprawieniu) ich dziecka. Ich postawa opierała się na tym, że poziom skarg na złe zachowanie dziecka przekroczył dopuszczalny limit. Nastawienie rodziców było schematyczne - gdy dziecko przejawia negatywne zachowania, należy ,je naprawić”, udzielając mu odpowiedniej pomocy.

\section{Proces wsparcia}

Dziecko w wieku powyżej 6 lat. Dziecko zawsze było umieszczane w centrum kryzysowym (placówce dla dzieci wymagających natychmiastowej pomocy) na wniosek rodziców. Dziecko nadal uczęszczało do swojej pierwotnej szkoły lub przedszkola, tak więc zachowano pierwotne środowisko społeczne dziecka. Zmienił się tylko pobyt dziecka, który określany był jako czasowy.

Od momentu przyjęcia do centrum dziecko ma przypisanego pracownika, który pracuje z nim nad wszystkim, co dla niego istotne - od adaptacji do zmiany mieszkania, przez pracę domową, odrabianie lekcji, po indywidualny program terapeutyczny. Kontakt z rodzicami jest wówczas kontrolowany, nieograniczony, 
ale zawsze odbywa się w obecności prowadzącego pracownika dziecka lub jego przedstawiciela.

Z rodzicami przeprowadzane są wywiady na temat ich związku, modeli edukacyjnych, podejścia do edukacji itp. Jeśli rodzice nie wyrażają zgody, rozmowy z nimi nie mają charakteru terapeutycznego, lecz odbywają się na poziomie mediacji.

Powrót dziecka do rodziny. Jest to kluczowy element całego procesu pracy z rodziną. Można odnieść wrażenie, że tylko ta część procesu ma charakter terapeutyczny (w tym względzie podobne są doświadczenia zarówno ośrodków z Opawy, jak i Pardubic).

Po powrocie dziecka do rodziny prowadzący pracownik odwiedza rodzinę dwa razy w tygodniu. Zwykle wówczas pomaga dziecku w odrabianiu lekcji lub monitoruje wykorzystanie jego wolnego czasu, towarzysząc dziecku. W tym samym czasie przychodzi również na jedno popołudnie w weekend. Te weekendowe modele wsparcia okazały się kluczowe z kilku powodów:

- weekend to inny okres dla dziecka i rodziny. W ciągu tygodnia rodzina ma ograniczony czas dla siebie i na konfrontację z innym;

- przypisany pracownik do pomocy dziecku to ten, który kieruje działaniami. Dziecko miało wówczas możliwość bycia aktywnym i zaangażowanym, a nie biernym obserwatorem w rodzinie;

- kluczowe w tej sytuacji jest doświadczenie rodziców, którzy mają szansę zaobserwować, że dziecko może zachowywać się inaczej niż dawniej. W większości przypadków to doświadczenie jest motywacją do zmiany w rodzinie, szczególnie w postawach rodzicielskich.

Dziecko poniżej 6 lat. Ta grupa dzieci charakteryzuje się tym, że nie mają jeszcze obowiązku szkolnego. Nie zostają one przyjęte na tygodniowy pobyt, ale jedynie na całodzienne pobyty, a wieczorem wracają do domu. Praca z dzieckiem odbywa się w grupie szkolnej - placówce dla dzieci wymagających specjalnej opieki.

Przyjmowanie dzieci odbywa się na wniosek rodziców - po kilku „wykluczeniach” dziecka z przedszkola z powodu problemów edukacyjnych. W takich sytuacjach istotne było to, że rodzic nie otrzymywał skarg na zachowanie dziecka z placówki, a uzyskiwał jedynie pozytywne informacje o jego umiejętnościach i postępach. Interesująca była prośba jednej z rodziny o nagranie wideo zachowania dziecka w trakcie codziennych zajęć w placówce, które były źródłem konfliktu w innych przedszkolach. Dziecko było chwalone za pozytywne zachowania, pomimo występowania u niego także negatywnych zachowań. W przypadkach przyjęcia dziecka na wniosek SPOD z powodu warunków niesprzyjających rozwojowi dziecka, rodzic co najmniej raz w tygodniu uczęszczał na zajęcia z zakresu realizacji potrzeb dziecka. Ta forma pomocy często zamieniała się w pomoc rodzicom w pozostaniu z dzieckiem. 


\section{Rodziny zdecydowane pozostać z dzieckiem - pomoc mieszkaniowa}

Ta forma pomocy jest kierowana do rodzin, które często rozwiązały obecny kryzys mieszkaniowy, pozostając w ośrodku dla dzieci, lub proponowana jest rodzinom, którym groziło wykluczenie społeczne. Jest to zatem bardzo specyficzna grupa rodzin, które zwykle mają problemy w dostępie do edukacji, a także narażone są na dziedziczenie ubóstwa.

Proces pracy z rodziną w formie wsparcia mieszkaniowego ma wspólne cechy we wszystkich organizacjach, które zajmują się tą usługą w Czechach - w Pardubicach, Ostrawie, Opawie, Hawierzowie, Strakonicach, Milovicach.

\section{Proces adaptacji i edukacji}

Cały pobyt jest planowany na okres trzech miesięcy. Proces adaptacji koncentruje się na zarządzaniu głównymi zmianami - opanowaniu wszystkich podstawowych zadań związanych z prowadzeniem gospodarstwa domowego, takich jak: zapewnianie usług socjalnych, przekwalifikowanie i poszukiwanie pracy, planowanie odpowiedniej diety, uczenie przedsiębiorczości, higieny osobistej, opieki nad dzieckiem. Następnie ustalany jest indywidualny plan pracy socjalnej i edukacji oparty na pięciu potrzebach dzieci, które zostały określone przez Matějčka.

Planowanie opiera się na modelu terapeutycznym, skoncentrowanym na wzmacnianiu umiejętności, tj. na tym, co może zrobić rodzic, a brakujące lub niewystarczające elementy są stopniowo wypracowywane w oparciu o już istniejące umiejętności. Pracownicy socjalni zakładają, że niektóre umiejętności będą opanowane przez rodzica tylko przy pewnym poziomie wsparcia, a także w kolejnych etapach rozwoju dziecka.

Ta część programu wsparcia jest wyzwaniem także dla sposobu myślenia osób wspierających w danej instytucji. Pracownicy ukierunkowani są najczęściej na standardy pracy z dziećmi, zupełnie odmienne od podejścia rodziców, którzy są klientami tychże ośrodków, wymagającymi wsparcia. Bardzo dużo zależy od postaw dyrektorów i ich wiary w możliwości zmian.

\section{Proces niezależności}

Proces niezależności to termin, który określa rodziny gotowe do tego, aby rozpocząć samodzielne życie. W tym procesie napotyka się znaczące problemy, które rozwiązywane są wspólnie z instytucjami, które od dawna świadczą usługi aktywizacji społecznej rodzinom z obszarów wykluczonych. 
Standardowa procedura wsparcia polegała na tym, że rodzina, która zamieszkała w niezależnym mieszkaniu, nadal otrzymywała wsparcie personelu ośrodka dla dzieci co najmniej dwa razy w tygodniu także w dawnym miejscu zamieszkania. Początkowo proces ten kształtowany był wspólnie z rodzinami. Chodziło wówczas o możliwość wykorzystania już istniejących relacji społecznych, bliskości dalszej rodziny, ich więzi z przyjaciółmi, które były ważne dla starszych dzieci.

Początkowo towarzyszył temu duży entuzjazm - żyję sam, mam pracę, wreszcie sam bez kontroli. Wówczas rodzice musieli przyjeżdżać do Centrum Dziecka tylko raz na dwa tygodnie, a pracownicy socjalni przychodzili do rodziny dwa razy w tygodniu. Jednak wskaźnik skuteczności pomocy mierzony w okresie 6 miesięcy wyniósł tylko około $20 \%$.

Szukając przyczyn tego stanu, odkryliśmy, że paradoksalnie podstawowym czynnikiem niepowodzenia było utrzymywanie bliskich więzi z dalszą rodziną i podtrzymywanie dotychczasowych kontaktów społecznych. Wykluczone miejscowości cieszą się wysokim stopniem więzi społecznych, a ich zachowania są odporne na zmiany. Punktem wyjścia w działaniu była w związku z tym zmiana podejścia do procesu niezależności - jako niezależność łączona ze zmianą miejsca zamieszkania. Tym procesem zarządzano tylko w Pardubicach, które jako miasto regionalne ma do dyspozycji większą liczbę mieszkań komunalnych, co dawało możliwości uruchamiania procesu deinstytucjonalizacji wsparcia.

\section{Przykład dobrej praktyki}

Obecnie podstawowym przykładem dobrej praktyki jest model Centrum Dziecka Veská, które jest częścią Pardubic. Cały proces wsparcia działa w ścisłej współpracy z miastem Pardubice. Kolejnym podobnym i funkcjonalnym modelem jest obiekt „House of Three Wishes, z.ú.” z Pragi, który jest bardzo motywujący do pracy ambulatoryjnej z rodzinami. Podstawowy proces pracy ze wsparciem rodzinnym jest do dziś niezmienny. Proces usamodzielnienia rodzin zostaje zapoczątkowany w mieszkaniach komunalnych na wspólnym osiedlu. Wsparcie rodzinne odbywa się w ciągu tygodnia, ale także w weekendy, ale przede wszystkim ma ono miejsce poza pierwotną, dotychczasową społecznością lokalną rodziny.

Pobyt rodziny w tym „mieszkaniu początkowym” jest planowany na 6 miesięcy, ale jest to zróżnicowane. Poziom oferowanego wsparcia stopniowo maleje, w zależności od nabytych umiejętności. Następnie rodzina zostaje przeniesiona do innego mieszkania w mieście. Rolą ośrodka dziecięcego jest, aby dziecko ponownie do niego nie trafiło, a rodzina odzyska dziecko ${ }^{12}$.

${ }^{12}$ M. Tauberová, Hradecké dny sociální práce: ... konference s mezinárodní účastí, Hradec Králové ... : sborník anotací, Gaudeamus, Hradec Králové 2019, s. 48. 
Praktyczne doświadczenie we wdrażaniu projektu:

1. Przypadek ojca z dzieckiem. Centrum Dziecka przyjęło na szkolenie ojca, który nagle został wdowcem i sam ze swoją 2-letnią córką. Ponieważ dotychczas nie byli oni małżeństwem z matką dziecka, a on jako ojciec małego dziecka na cały dzień wyjeżdżał do pracy, nie miał umiejętności opieki nad córką i musiał nauczyć się dbać o dziecko w ramach kolejnych dwóch lat przyznanej opieki rodzicielskiej. Podczas pobytu w ośrodku dziecięcym jego obecność przynosiła pozytywne rezultaty, było to także motywacją do rozwijania kompetencji dla innych matek z dziećmi. Jednak po przeprowadzce do mieszkania „początkowego” okazało się, że ojciec nie opanował wszystkich umiejętności i potrzebował wsparcia. Rozwiązaniem okazało się przeniesienie go do Domu Zdrowia Psychicznego, gdzie ze względu na stałą obecność pracowników socjalnych mógł uzyskać wyższy poziom wsparcia i dzięki temu działać w normalnym środowisku społecznym. Zakłada się, że wraz ze zmieniającymi się potrzebami dziecka będzie on musiał otrzymać kolejny poziomu wsparcia, jeśli chcemy utrzymać istniejące więzi emocjonalne między ojcem a dzieckiem, które są bardzo wysokie, jednak w obecnym stanie nie można pozwolić na całkowitą niezależność.

2. Przypadek matki. 16-letnia matka została przyjęta do Centrum Dziecka na szkolenie w zakresie opieki nad dziećmi. Po dwóch miesiącach dziewczyna opuściła ośrodek z partnerem, nie wykazując zainteresowania dzieckiem, a następnie wyraziła zgodę na adopcję. Ten scenariusz powtarza się przez kolejne dwa lata, w ciągu których opuszcza ona dziecko, a następnie dziecko w wieku 8 miesięcy zostaje objęte opieką zastępczą. Matka mając już 25 lat, ponownie przyjeżdża z kolejnym dzieckiem do Centrum Dziecka. Przechodzi cały proces edukacji, proces życia w mieszkaniu początkowym. Następnie przeprowadza się do mieszkania z umową najmu. Ma partnera i mimo roku samodzielnego życia, gdy jest w stanie podjąć rolę rodzica ona sama nie wykazuje zainteresowania własnymi dziećmi, które obecnie mieszkają poza rodziną.

3. Przypadek rodziny w tarapatach. Młoda matka została przyjęta do ośrodka dziecięcego. Wcześniej po porodzie mieszkała w schronisku dla matki i dziecka. W procesie wspierania ich kompetencji rodzicielskich ujawnił się łagodny deficyt intelektualny. W procesie uniezależnienia nawiązano współpracę z pozarządową organizacją non-profit, która miała zapewnić wsparcie rodzinie w kolejnych latach. W następnym roku po samodzielnym funkcjonowaniu matka za namową swoich rodziców przeniosła się do nich, zamieszkała w dawnym miejscu. Dzięki tej zmianie wielopokoleniowa rodzina osiągnęła wyższe świadczenia społeczne i macierzyńskie. Niestety wraz ze zmianą miejsca zamieszkania matka przejęła dawne, dysfunkcyjne modele wychowania, a dziecko ponownie znalazło się w kategorii dzieci zaniedbanych przez rodziców.

Należy zauważyć, że ośrodki dla dzieci rejestrują bardziej udane procesy rozwijania kompetencji rodzicielskich niż te, które się nie powiodły. Sukces zależy 
jednak od możliwości zmiany miejsca zamieszkania i zerwania więzi z pierwotną rodziną pochodzenia. Jednak procedura ta nie odpowiada znaczeniu ani literze ustawy o społecznej i prawnej ochronie dzieci (§5).

Zdecydowana większość rodziców, którzy zaniedbują swoje dzieci, nie przejmuje się zmianą postaw i oddaniem dziecka pod opiekę zastępczą, a nowi rodzice ich dziecka są mile widzianą odmianą w ich codziennym życiu.

\section{Wnioski}

Jako pracownicy systemu SPOD dysponujemy narzędziami bardzo wysokiej jakości:

1. doświadczenie w pracy w ramach potrzeb rozwojowych dzieci, które zapewniają nam wysokiej jakości podstawy do oceny stanu rodziny, ale także podstawy do planu rozwoju kompetencji rodzicielskich;

2. nowe kompetencje pracowników socjalnych wynikające z norm prawnych mediacja, spotkania terapeutyczne rodziców;

3. nowe narzędzia - indywidualny plan rozwoju rodziny i dziecka, który nakazuje rodzicom i dziecku uczestniczyć w planowaniu zmian i interwencji w rodzinie - dekret nr 422/2012.

4. ciekawe obiekty w ośrodkach dla dzieci, które charakteryzują się wysokiej jakości infrastrukturą i zatrudniają doświadczone zespoły pracowników z różnych dziedzin.

5. profesjonalna i interesująca oferta usług - od usług w ramach SPOD po usługi w ramach usług socjalnych.

6. w procesie rehabilitacji rodziny zakładamy, że rodzicielstwo jest cechą osobowości.

Słabe strony zmian:

1. Niechciane dzieci stają się „dzieckiem preferowanym” ze względu na możliwość otrzymania wsparcia - ponad 70\% to dzieci zaniedbane przez rodziców (zob. tab. 1).

2. Rodzina biologiczna, która żyła w wykluczonej i negatywnie postrzeganej grupie społecznej, nagle znalazła się w centrum uwagi wsparcia społecznego i organizacji pomagających. Dzięki osiągniętej niezależności rodzina traci te przywileje uwagi.

3. Zagrożone dziecko często staje się drogą do lepszych warunków materialnych dla rodziny.

4. Najbardziej narażone rodziny odmawiają współpracy, a dziecko pozostaje w rodzinie z powodu tak skonstruowanych norm prawnych, które pozwalają na to, dopóki nie jest zagrożone zdrowie lub życie. 
5. Aby model mógł odnieść sukces, należy zapewnić wysoki poziom wsparcia ze strony władz regionalnych i współpracy z miastami w zakresie możliwości przeprowadzania rodzin poza pierwotną lokalizację.

6. Brak zgody na instytucjonalne ułatwienia ze strony pozarządowych organizacje non-profit.

Praktyczne doświadczenie pokazuje, że istnieją konieczne warunki do wypełnienia wskazań prawa w SPOD. Pomimo sytuacji, w której możliwe jest zapewnienie takiej formy pomocy nawet niewielkiej liczbie rodzin, oczywiste jest, że wyspecjalizowane miejsca pracy łączące opiekę stacjonarną i ambulatoryjną mają głębokie znaczenie. Ze względu na sytuację, w której pracownicy socjalni OSPOD rejestrują ponad 7000 dzieci zagrożonych zaniedbaniem, centra dla dzieci mogą pomóc tylko w niewielkim stopniu, ale nie mają kolejki na tę usługę. Rodziny niejednokrotnie nie chcą niczego zmieniać, a pytanie brzmi, czy intencją prawodawcy określającego wspieranie rodziny biologicznej jest krzywda dziecka. Być może warto zastanowić się, czy ta zmiana systemowa spowodowała raczej nową, kontrolowaną przez państwo formę nadużyć.

Konieczna jest oczywiście profilaktyka w sensie wsparcia nowej roli rodziny jako takiej, ale szczególnie istotna jest edukacja do odpowiedzialności rodzicielskiej oraz zmniejszenie liczby obszarów wykluczonych, które same w sobie stanowią ryzyko dla rodziny i dziecka. W świetle przedstawionych wyników badań, otwierają się nowe zadania dla administracji państwowej i samorządu w ramach wspierania rozwoju rodzin i zachęcania do współpracy między różnymi typami instytucji.

\section{Literatura}

Bowlby J., Vazba: teorie kvality raných vztahů mezi matkou a dítětem, Portál, Praha 2010.

Gilbert N., Parton N., Skivenes M., Child protection systems: international trends and orientations, Oxford University Press, New York 2011.

Langmeier J., Matějček Z., Psychická deprivace v dětství, Karolinum, Praha 2011.

Matějček Z., Co děti nejvíc potřebují: Eseje z dětské psychologie, Portál, Praha 1994.

Škoviera, A. Resocializační pedagogika - kontexty a trendy, Univerzita Pardubice, Pardubice 2018.

Tauberová M., Hradecké dny sociální práce: ... konference s mezinárodní účastí, Hradec Králové ... : sborník anotací, Gaudeamus, Hradec Králové 2019.

\section{Źródła elektroniczne}

Schneiberg, F., Dětská centra - moderní forma komplexní péče o ohrožené děti, Pediatrie pro praxi.

https://www.pediatriepropraxi.cz/pdfs/ped/2011/02/20.pdf [28.12.2019]. 
Ministerstvo Práce a Sociálních Věcí; Statistická ročenka z oblasti práce a sociálních věcí, Praha 2020, https://www.mpsv.cz/web/cz/statisticka-rocenka-z-oblasti-prace-asocialnich-veci [8.08.2020].

Schramm D., Futris T., Bradley R., 2013; ChildWelfare and HealthyMarriage and RelationshipEducation: A Research to PracticeBrief, https://library.healthymarriageandfamilies. org/cwig/ws/library/docs/MARRIAGE/Blob/85819.pdf?w=NATIVE(\%27TITLE+ph+ is $+\% 27 \% 27$ Child+Welfare+and+Healthy+Marriage+and+Relationship+Education:+A +Research+to+Practice+Brief\%27\%27\%27)\&upp=0\&rpp=25\&order=native(\%27year/ Descend\%27)\&r=1\&m=1 [20.12.2019].

\section{Akty prawne}

Kodeks cywilny (Dz. U. z 2012 r. Nr 89), https://www.zakonyprolidi.cz/en/2012-89 [15.12. 2019].

Rozporządzenie 473 / 2012Sb. Dekret w sprawie wdrożenia niektórych przepisów ustawy o społecznej i prawnej ochronie dzieci, https://www.zakonyprolidi.cz/en/2012-473 [16.12.2019].

Ustawa o ochronie socjalnej i prawnej młodzieży (Dz. U. z 1952 r. Nr 69), https://www. zakonyprolidi.cz/en/1952-69 [19.12.2019].

Ustawa o społecznej i prawnej ochronie dzieci (Dz. U. z 1999 r. Nr 359), https://www. zakonyprolidi.cz/hledani?text=359\%2F1999 [18.12.2019].

Ustawa o usługach społecznych (Dz. U. z 2006 r. Nr 109), https://www.zakonyprolidi.cz/ hledani?text=109\%2F2006 [28.12.2019].

Zarejestrowana ustawa o partnerstwie (Dz. U. z 2006 r. Nr 115), https://www.zakonyprolidi. cz/en/2006-115 [27.12.2019]. 
